\title{
Banana pell pellets for animal feed
}

\section{Pellest de casca de banana para alimentação amimal}

Cristian Ferreira ${ }^{1}$, Miguelangelo Ziegler Arboitte ${ }^{1 *}$, Franciele de Oliveira ${ }^{1}$, Juliana Muliterno

Thurow $^{1}$, Liliane Cerdotes ${ }^{1}$, Leandro Lunardi ${ }^{1}$, Letícia de Castilhos ${ }^{1}$

\begin{abstract}
The objective was to determine the exact moisture percentage for the formation of pellets from the banana peel, residues of banana candies, and the bromatological analysis of the final product. For the of the peel of banana, 10 different dehydration times were performed: zero; two; four; six; eight; ten; twelve; fourteen; sixteen and eighteen hours of dehydration, with four replicates each treatment. The exact moisture percentage for pellet formation was $18.84 \%$ moisture. The final product presented in its bromatological composition $81,16 \%$ of DM, $8,59 \%$ of $\mathrm{CP}, 26,8 \%$ of TND , $71,48 \%$ of NDF, $54,64 \%$ ADF, $0,8 \%$ of EE, $13,43 \% \mathrm{MM}, 86,54 \%$ of OM, $0,22 \%$ of P e $0,068 \%$ of $\mathrm{K}$. Evaluations in animal models should be performed in place of corn to determine the replacement levels in the diets and the performance of the animals.
\end{abstract}

Keywords: Food; Musa ssp.; Pelleting; By-products

\section{RESUMO}

O objetivo foi determinar a porcentagem de umidade exata para a formação dos pellets da casca de banana, resíduos da fabricação das balas de banana e a análise bromatológica do produto final. Para a peletização das cascas foram testados 10 diferentes tempos de desidratação: zero; duas; quatro; seis; oito; dez; doze; quatorze; dezesseis e dezoito horas de desidratação, com quatro repetições cada tratamento. A porcentagem de umidade exata para a formação dos pellets foi de $18,84 \%$ de umidade. O produto final apresentou na sua composição bromatológica $81,16 \%$ de MS, $8,59 \%$ de PB, 26,8\% de NDT, 71,48\% de FDN, 54,64\% FDA, $0,8 \%$ de EE, $13,43 \% \mathrm{MM}, 86,54 \%$ de MO, $0,22 \%$ de P e $0,068 \%$ de K. Avaliações em modelos animais devem ser realizadas em substituição ao milho para determinação dos níveis de substituição nas dietas e o desempenho dos animais.

Palavras-chave: Aliemntação; Musa ssp.; Peletização; Co-produto;

\footnotetext{
${ }^{1}$ Instituto Federal Catarinense Campus Santa Rosa do Sul 1.

*E-mail: Miguelangelo.arboitte@ifc.edu.br
} 


\section{INTRODUÇÃO}

Produced in most tropical countries banana (Musa spp.) in Brazil accounts with $6 \%$ in world production (DOSSA and FUCHS, 2017), placing Brazil in fourth place, with an average production of 6.7 million tons (FAO, 2017), the most consumed fruit in the country, where more than $98 \%$ of national production is absorbed in domestic consumption (ABF, 2018).

To increase production, local techniques and research are invested, with the objective of offering a better quality product to the consumer market aiming at greater financial return. Associations and partnerships between farmers and research centers increasingly enable improvements in this production chain. The state of Santa Catarina has stood out with regard to productivity, although the volume of production is lower than the states of São Paulo and Bahia, producing an average of 21,784 mil kg.hectare ${ }^{-1}$ (PIMENTEL, 2006).

As a result of the high production of this fruit, the exploitation of its potential by the industries has intensified. As a result, it increased the commercial range for producers, enabling choices for the sale of (AQUINO, 2013). Of the fruit, about $2.5 \%$ to $3.0 \%$ are industrialized, in the form of jams and bullets, in which the resulting product $33 \%$ are absorbed into the domestic market and the remainder is exported (BORGES and SOUZA, 2004).

During the transformation of the fruit into other more elaborate products, such as the bullet, it is estimated that $40 \%$ of the production is waste (LEOBET, 2016) where $85 \%$ are barks, $15 \%$ are peduncles and less than $1 \%$ are worthless fruits, waste in which no correct destinations are given, may lead to problems of environmental contamination.

Banana crop residues have desirable physical-chemical characteristics (ALKARKHI et al., 2011), being taking advantage of various parts of the plant in the feeding of cattle with that observed by Souza et al. (2016) and Casas et al. (2020), nutritional value is considerable for ruminant feeding, residues "in natura" may present in its bromatological composition, crude protein values between 6.3 and $16.0 \%$, ether extract of 2.210 the. $9 \%$, carbohydrates of 26 the $46 \%$; mineral matter de 6,4 the $12,9 \%$, gross energy of 4,01 the 4,35 Mcal.kg-1 in DM (EMAGA et al., 2007; LEOBET, 2016), can be stored in the form of silage for use as bulky, and the obstacle to this form of conservation is the water content that may represent 92.3 a $78.6 \%$ of weight. It can be 
ensiled in mixture with other residues for the feeding of ruminants as demonstrated by DORMOND et al. (1998), CONTE (2017) and MORAES et al. (2021).

Another form of conservation is the transformation of waste into pellets, as with citrus pulp, which can be supplied as a supplement to ruminants (ANDRADE et al.; 2015) or mixed in silages to reduce moisture from the ensiled material (GRIZZOTO et al. 2017) or to enrich making hay materials (GAVIOLI and LIMA, 2020).

Nutritional characteristics express economic value for animal feed, especially when used strategically in critical periods, where there is low forage production, complementing the feeding of animals, improving livestock rates, provided that an appropriate form is found for its conservation, as the deterioration occurs very quickly due to the moisture levels in the product, together with the fermentation of carbohydrates associated with high temperature (SOUZA et al., 2016). In the feed market, the use of farm-industry by-products for feed production, reduce production costs by increasing production rates (LINHARES, 2016), in addition to minimizing environmental risks, turning a problem into noble meat and milk products.

The main obstacles in the use of banana peel as animal feed is the high moisture content and the variation that occurs in the composition, hindering the transport, storage and formulation of diets containing this by-product (CONTE, 2017). To improve the use of by-products, the industry uses the transformation process, which consists of the use of dehydration, temperature and pressure, improving the ability to store the product for longer periods without fermentation and deterioration, process that forms a product with particles of specific diameters (SANTOS, 2006), with controlled humidity.

The experiment aimed to determine the percentage of exact moisture for the formation of pellets of residues from the manufacture of banana candies, in addition to performing the bromatological analysis of the final product.

\section{MATERIAL AND METHODS}

The material used to conduct the experiment was banana peel, derived from the production of candies. The experiment was initially conducted 11 dehydration times (treatments) determined so that the product used for the production of pellets would have different levels of dehydration from the raw material, being composed by the treatments: control "in natura"; dehydration by: two; four; six; eight; ten; twelve; fourteen; sixteen; 
eighteen and twenty-two hours in an air oven at $60^{\circ} \mathrm{C}$. Each treatment consisted of four repetitions, and sampled from a $1.250 \mathrm{~kg}$ banana peel "in natura".

The dehydration procedure was performed in a forced air oven at a constant temperature of $60^{\circ} \mathrm{C}$. Samples before being placed in the greenhouse were weighed and after the end of dehydration time were again weighed and submitted to the fur-eat process carried out with the aid of a manual meat machine $\mathrm{N}^{\mathrm{o}} 10$ Coyote ${ }^{\circledR}$ of the brand. In the course of this process the material passes through the snail that performs pressure and boosts its output by a $5 \mathrm{~mm}$ disc with numerous perforations. At the end of the procedure, the sample that presented the best pellet texture was dried until it had $82 \%$ dry mass, $18 \%$ moisture content, and the required by the legislation of the MAPA (2009), and submitted to bromatological analysis.

During the dehydration process, data on how much water the shell lost every two hours was extracted, the data were placed in a table and thus representing a straight through regression equation.

For the bromatological analysis, the samples of the banana pellet with the best texture were identified, crushed in a mill type Willey and analyzed in triplicates the following components: Dry matter (DM), crude protein (CP), ether extract (EE), neutral detergent fiber $(\mathrm{NDF})$, acid detergent fiber (ADF), organic matter (OM) and mineral (MM), phosphor, potassium, at the bromatology laboratory of Instituto Federal Catarinense - Campus Santa Rosa do Sul.

The determinations of dry matter, crude protein and ether extract followed the methodology described by Silva e Queiroz (2006). The Neutral detergent fiber and acid detergent fiber were determined according to the procedures described by Senger et al. (2008).

The concentration of total digestible nutrients (TDN) was estimated according to the equation proposed by Capelle et al. (2001) for foods in which it the use the participation of the ADF and concentrate the according to the equation:

$$
\mathrm{TDN} \%=60,04-(0,6083 \mathrm{X} \mathrm{ADF}) \text {; }
$$

To determine the share of total carbohydrate (\%TCHOT) and not structural carbohydrate (\%NSC) the equations described of Sniffen et al. (1992):

$$
\begin{gathered}
\% \mathrm{TCHOT}=100-(\% \mathrm{CP}-\% \mathrm{MM}-\% \mathrm{EE}) ; \\
\% \mathrm{NSC}=100-(\% \mathrm{NDF}-\% \mathrm{CP}-\% \mathrm{MM}-\% \mathrm{EE}) ;
\end{gathered}
$$


For an analysis to determine the content phosphorus $(\% \mathrm{P})$ and potassium $(\% \mathrm{~K})$ was according to the methods for Malavolta et al. (1997).

\section{RESULTS AND DISCUSSION}

Samples of residues from the banana candy industry required 22 hours of dehydration at $60^{\circ} \mathrm{C}$ to present ideal texture for the formation of pellets, with the participation of $81.16 \%$ DM. The dry matter is the representation of nutritional constituents present in products, such as crude protein, carbohydrate, ether extract, neutral detergent fiber, acid detergent fiber, minerals, important for balancing the animal diet (MEDEIROS and MARINO, 2015).

It was verified with the use of the regression equation, that the material with $81.16 \%$ of DM allowed the best aggregation of the studied material, but even with the great reduction of water, there is still the need to reduce the share of water to $12 \%$, to prevent nutrient degradation, which can occur by the action of fungi, bacteria, oxidations, Mailard reaction, and other undesirable aspects that can cause food poisoning and impair the performance of animals, and may even cause death.

The use of pellet should be evaluated in different ways, including the issue of costbenefit and nutritional. As for the economic issue, it is important to highlight the need for dehydration and palletization practices, which involve, but improve food conservation by reducing the proliferation of pests in foods with a lot of water participation in their composition, and also the issue of regional availability, such as banana peel.

It is important to note that the formation of banana peel in pellets aims to improve the conservation of the product, which can be stored by longer period in enhancement the banana peel. Banana peel "in natura" presents a high degree of deterioration when in contact with air, causing the rejection of animals and food waste.

On the nutritional issue it is important to compare the composition of pellets from banana co-products with maize for being the main energy food used in animal feed, and widely used in supplementation of field or confined cattle.

The bromatological constituents will be discussed with reference to maize, taking databases made available by NRC (2000); Garcia Neto (2010); Valadares Filho et al. (2016) and FEDNA (2019). Table 1 includes descriptive analyses of the evaluated bromatological parameters. 
Table 1 - Descriptive analysis of the percentage participation based dry matter of crude protein (CP), ether extract (EE), neutral detergent fiber (NDF), acid detergent fiber (ADF), total carbohydrate (TC), not structural carbohydrate (NSC), total digestible nutrients (TDN), mineral matter $(\mathrm{MM})$ e organic matter $(\mathrm{OM})$ of banana peel pellet sample

\begin{tabular}{lccccccccc}
\hline & CP & EE & NDF & ADF & TC & NSC & TDN & MM & OM \\
& & & & & & & & & \\
\hline & & & & & & & & & \\
\hline Min & 8.1 & 0.6 & 67.1 & 52.3 & 76.5 & 2.7 & 24.6 & 13.0 & 86.2 \\
Max & 9.6 & 1.0 & 73.8 & 58.3 & 78.0 & 10.9 & 28.2 & 13.8 & 87.0 \\
Means & 8.5 & 0.8 & 71.5 & 54.6 & 77.2 & 5.7 & 26.8 & 13.5 & 86.5 \\
SE & 0.2 & 0.1 & 2.2 & 1.9 & 0.5 & 2.6 & 1.1 & 0.2 & 0.2 \\
Var & 0.3 & 0.05 & 14.6 & 10.9 & 0.6 & 21.0 & 3.8 & 0.2 & 0.2 \\
DP & 0.5 & 0.22 & 3.8 & 3.2 & 0.8 & 4.6 & 2.0 & 0.4 & 0.4 \\
CV & 6.8 & 27.9 & 5.4 & 5.9 & 1.0 & 80.9 & 7.3 & 3.2 & 0.5 \\
\hline
\end{tabular}

$\overline{\text { Min - minimum value observed; Max - maximum value observed; SE - standard error; Var - }}$ Variance; $\mathrm{SP}$ - standard deviation; CV - Coefficient of variation

The share of crude protein was on average $8.6 \%$ in banana peel pellet, and this value was above the critical level of $7 \%$ minimum requirement for ruminants develop ruminal fermentation (LAZARINI et al., 2009). In banana residues Dormond et al. (1998) observed a value of $10.45 \%$ in ripe banana peel, while Emaga et al. (2007) observed values de CP de 6.3 a $11.2 \%$ in the peel at different stages of banana maturation, demonstrating that the more mature the banana the peel has the higher protein value.

Values of CP in 10.8\% (NRC, 2000), 8.0\% (GARCIA NETO, 2010), 9.0\% (VALADARES FILHO et al., 2016) and 7.3\% (FEDNA, 2019) are reported in corn grains, and banana peel pellet may be a corn substitute food in the crude protein factor.

The ether extract verified in the banana peel pellets was $0.8 \%$ (Table 1), value lower than that of maize than in the databases consulted, which presented values of 4.1, 3.3, 4,0 and 3.3\%, NRC (2000), Garcia Neto (2010), Valadares Filho (2016) and FEDNA (2019), respectively. As the fat present in food may be a performance limiter of ruminants, 
the contents in the feed should be in the range of 3 the 5\% (LANA, 2005), already Medeiros et al. (2015) mention that the level of ether extract in the ruminant diet should be between 3 the $6 \%$, being values above $6 \%$ limiting by causing negative effects on ruminal degradation, decreasing feed efficiency, negatively affecting animal performance.

The participation of neutral detergent fiber (NDF) observed in the pellet of the observed banana peel was 71.5\% (Table 1), while Dormond et al. (1998) observed value of $50,1 \%$ NDF in peels banana. The value observed in $71,5 \%$ NDF is considered as a limiting factor in food intake, however, because it is a pellet with shorter fiber structures or as mentioned by Medeiros et al. (2015) foods that have thin cells, the influence of NDF may be less and may not cause reduced consumption that may affect animal performance.

Banana peel by comparting the protective part of the fruit, the high participation of NDF in banana peel pellet, resembles other co-products from the fruit peel, such as passion fruit and acerola, values of 66.1 and $72.6 \% \mathrm{NDF}$ as reported of Valadares Filho et al. (2016), or in apple pulp, beet root pulp and grape pomace value of 50.1, 44.3 and $48.6 \%$ NDF, respectively (FEDNA, 2019). In corn grain values of NDF are lower than those found in the banana peel pellet, presenting values of 10.8, 8.0,13.06 and 9.0\%, NRC (2000), Garcia Neto (2010), Valadares Filho (2016) e FEDNA (2019), respectively.

The cellulose and lignin fraction of a food that makes up acid detergent fiber (ADF) was verified in the banana peel pellet with the participation of 54.6\% (Table 1), to superiors $42.8 \%$ observed from Dormond et al. (1998) in peels banana. In apple pulp, beet root pulp and grape pomace value of ADF related in FEDNA (2019) they are 36.2, 22.8 and $46.7 \%$ NDF, respectively. Value above the 3.3, 3.2 and $2.8 \%$ related in NRC (2000), Garcia Neto (2010) e FEDNA (2019), respectively, from corn.

For good rumination to occur, it is necessary to balance the rate and extent of structural carbohydrate degradation (TC) (slow fermentation carbohydrates) and nonstructural carbohydrates (NSC) by rumen microorganisms (MACEDO JUNIOR et al. 2007). The verified values of TC and NSC in pellet was from 77.2 and 5.7\%, respectively (Table 1), which characterizes the product as a rumination stimulator and that would not cause excessive rapid fermentation which is responsible for the production of fatty acids ruminal $\mathrm{pH}$, by exceeding the buffering capacity of the salivary bicarbonate system, $\mathrm{c}$ as what occurs when diets have in their composition high participation of grains such as corn 
grain, which has an inverse relationship to that observed in the peels banana pellet, corn grain, the share of non-structural carbohydrates is $72.3 \%$ (VALADARES FILHO, 2016). Whereas in as apple pulp, beet root pulp and grape pomace the participation of nonstructural carbohydrates are intermediate with values of the 36.8, 40.2 and $22.1 \%$.

The high observed participation of NDF, ADF, structural carbohydrates and the low participation non-structural carbohydrates of banana peel pellets may explain the low energy calculated in this food. The participation of total digestible nutrients (TDN) of the peel and banana pellets observed was $26.8 \%$ (Table 1), providing approximately 1.0 Mcal. of DE. $\mathrm{kg}^{-1} \mathrm{DM}$, energy value below the energy values of other products such as apple pulp, beet root pulp and grape pomace, that providing 2.2; 2.4 e 2.2 Mcal. of DE.kg${ }^{1}$ DM (FEDNA, 2019). Low energy can lead to reduced food consumption due to lack of energy. In practice, bulky foods have lower levels of TND (MEDEIROS et al., 2015).

Minerals not representing all inorganic substances, as some salts can volatize (Salman et al., 2010). The average contents of MM and OM verified in the peels banana pellets were of 13.4 and $86.5 \%$, respectively (Table 1 ). In the forage offered to cattle the phosphorus usually presents deficit, mainly because the soils where they are implanted are poor in this mineral, which consequently decreases its bioavailability, failing to meet the nutritional needs of the animal (TOKARNIA et al. 2000; LANA, 2005). However potassium is found in adequate amounts and at times can negatively interfere with the physiology of the animal (PEDREIRA and BERCHIELLI, 2011), mainly in cows in the period preceding parition, which makes it important to determine this two mineral in the supplements to be used for feeding ruminants (ARBOITTE et al., 2019). According to Medeiros and Marino (2015) and Medeiros et al. (2015) phosphorus and potassium deficiency can reduce the intake and consequently the decrease in animal performance of cattle.

In table 2 the participation of phosphorus and potassium present in banana peel pellets are represented, with values of 0.22 and $0.07 \%$. In green banana flour with peel, Vargas and Lobo (1992) verified levels de P total of 0.13\%, while whereas Dormont et al. (1998) observed in ripe banana peel value of $0.19 \%$ of $\mathrm{P}$ and $9 \%$ of $\mathrm{K}$. 
Table 2- Percentage contents phosphorus and potassium present in banana peels pellets

\begin{tabular}{lcc}
\hline & Phosphorus, $\%$ & Potassium, $\%$ \\
\hline Minimum & 0,20 & 0,07 \\
Maximum & 0,25 & 0,07 \\
Means & 0,22 & 0,07 \\
Standard error & 0,01 & 0,001 \\
Variance & 0,06 & 0,002 \\
Standard deviation & 0,02 & 0,015 \\
Coefficient of variation & 0,11 & 0,22 \\
\hline
\end{tabular}

How foods are classified according to energy levels, fiber and protein (LANA, 2005) banana peel pellets would be classified as bulky food of low fibro-rich energy value. Can be instilled in the diet of ruminates in the form of a dietary supplement when forage deficit occurs, as well as being used in the production of rabbit feed, due to the content of $\mathrm{ADF}$, meeting the needs of this animal species that present requirements between 15 and $18.5 \%$ of the DM of the diet (KLINGER and TOLEDO, 2018) instead of the use of shells of very low nutritional quality such as rice, intestinal disturbances in animals due to the abrasiveness of the material.

\section{CONCLUSIONS}

The exact percentage of moisture for the formation of the pellets of the residues of the manufacture of banana candies was $18,84 \%$ moisture, presenting bromatological characteristics low energy feature in front of corn grain food. Evaluations in animal models should be carried out in place of corn to determine the replacement levels in the diets and the performance of the animals. 


\section{REFERÊNCIAS}

ALKARKHI, A. F. M. et al. Comparing physicochemical properties of banana pulp and peel flours prepared from green and ripe fruits. Food Chemistry, v.129, n. 2, p. 312318. 2011.

ABF - Anuário Brasileiro da Fruticultura. Banana. Ed. Gazeta, 2018.

AQUINO, B. N. Produção de banana-passa obtida por processos combinados de desidratação osmótica e secagem convectiva. Monografia (Graduação em Ciências Agrárias) - Universidade Estadual da Paraíba, Catolé do Rocha (PB), 2013.

ARBOITTE, M. Z.; RIBEIRO, W. B.; BOSS, L. Produção de biomassa e avaliação bromatológica de cultivares de capim elefante Pennisetum purpureum Schum. no período outono inverno. Nucleus Animalium, v.11, n.2 p. 109-122, 2019.

BORGES, A. L.; SOUZA, L. S. O cultivo da bananeira. Cruz das Almas: Embrapa Mandioca e Fruticultura, 2004. p. 279.

CASAS, B.A.D. et al. Uso de resíduos da região norte do estado de Santa Catarina na alimentação de bovinos sobre a saúde ruminal e hepática. Brasilian Journal Development, v.6, n.4, p. 19357-19379, 2020.

CAPELLE, E. R. et al. Estimativas do valor energético a partir de características químicas e bromatológicas dos alimentos. Revista Brasileira de Zootecnia, v.30, n. 6, p. $1837-1856.2001$.

CONTE, R. A. Conservação e utilização do subproduto da banana como alimento alternativo para vacas leiteiras. Dissertação (Mestrado) - Programa de Pós-Graduação em Zootecnia, Área de Concentração Ciência e Produção Animal, da Universidade do Estado de Santa Catarina (UDESC), Chapecó (SC), 2017.

DORMOND, H., BOSCHINI, C., ROJAS-BOURILLON, A. Efecto de dos niveles de cascara de banano maduro sobre la producción láctea en ganado lechero. Agronomia Costarricense, v.22, n.1, p. 43-49. 1998.

DOSSA, D.; FUCHS, F. Banana: produção, mercado e preços na CEASA-PR. 2017.

EMAGA, T. H., et al. Effects of the stage of maturation and varieties on the chemical composition of banana and plantain peels. Food chemistry, v.103, n.2, p.590-600, 2007.

FAO - Food and agriculture organization of the united nations. Crops. 2017.

FEDNA - Fundación española para el desarrollo de la nutrición animal. Tablas FEDNA de composición y valor nutritivo de alimentos para la fabricación de piensos compuestos (4 edición). C. de Blas, P. García-Rebollar, M. Gorrachategui y G.G. 
Mateos. Fundación Española para el Desarrollo de la Nutrición Animal, 2019. Madrid. $604 \mathrm{p}$.

GARCIA NETO, M. Programa Prático para Formulação de Ração - PPFR. 2010.

GAVIOLI, I. L. de C.; LIMA, J. A. de. Ensilagem de Alfafa Submetida ao Emurchecimento ou Enriquecida com Polpa Cítrica Brazilian Journal of Animal and Environmental Research. v.3, n.3, p.2719-2722. 2020.

INSTITUTO DE GEOGRAFIA E ESTATÍSTICA-IBGE. Pesquisa da agropecuária municipal: tabelas. 2018 .

KLINGER, A. C. K.; TOLEDO, G. S. P. de. Cunicultura. Didática e prática na criação de coelhos. Ed. UFSM, 2018, 128p.

LANA, R.P. (2005). Nutrição e alimentação animal (mitos e realidades). Viçosa, MG: UFV, 2005. 344p.

LEOBET, J. Casca de banana (Musa cavendishii) como fonte de energia e caracterização do resíduo mineral fixo. Dissertação (Mestrado) -Universidade Federal de Santa Catarina, Centro de Ciências Agrárias. Programa de Pós-Graduação em Ciências dos Alimentos, Florianópolis, 2016.

LIMA, M. B.; SILVA, S. de O.; FERREIRA, C. F. Banana: O produtor pergunta, a Embrapa responde. Brasília, DF: Embrapa Mandioca e Fruticultura. 2 ed. p.218, 2012.

LINHARES, C. A. M. Processo de fabricação de ração para suínos. Trabalho de Conclusão de Curso (Graduação) - Universidade Federal do Ceará, Centro de Ciências Agrárias, Curso de Zootecnia, Fortaleza, 2016.

MACEDO JUNIOR, G.L.; ZANINI, A. de M.; BORGES, I.; PÉREZ, J.R.O Qualidade da fibra para a dieta de ruminantes. Ciência Animal, v.7, n.1, p.7-17, 2007.

MALAVOLTA, E.; VITTI, G.; OLIVEIRA, S. A. Avaliação do estado nutricional das plantas: princípios e aplicações. 2. Ed. Piracicaba: POTAFOS. 319p.1997.

MAPA. PORTARIA No 3, DE 22 DE JANEIRO DE 2009. MINISTÉRIO DA AGRICULTURA, PECUÁRIA E ABASTECIMENTO, 2009.

MEDEIROS, S.R. de; MARINO, C.T. Valor nutricional dos alimentos na nutrição de ruminantes e sua determinação. In: Nutrição de Bovinos de Corte: Fundamentos e Aplicações. Ed. MEDERIOS, S.R. de; GOMES, R. da C.; BUNGESTAB, D.J. Brasília, DF: Embrapa, 2015. 176 p.

MEDEIROS, S.R. de; ALBERTINI, T.Z.; MARINO, C.B. Lipídios na nutrição de ruminantes. In: Nutrição de Bovinos de Corte: Fundamentos e Aplicações. Ed. 
MEDERIOS, S.R. de; GOMES, R. da C.; BUNGESTAB, D.J. Brasília, DF: Embrapa, 2015b. 176 p.

MORAES, J. E., REIS, T., FUZITANI, E., DAMATTO JÚNIOR, E., MAIOLI, C, B. S., W. V., BUENO, M; PAULINO, V.T. Pupunha heart of palm residue silage as na option roughage for ruminantes. Boletim de Indústria Animal, v.78, p. 1-23, 2021.

NATIONAL RESEARCH COUNCIL - NRC. Nutrient requirements of beef cattle. 7. rev. ed. Washington, D.C.: National Academic Press, 2000. 242p.

PEDREIRA, M. DOS S.; BERCHIELLI, T.T. (2011). Minerais. In: Nutrição de Ruminantes, $2^{\circ}$ Ed. Editores: Berchielli; Pires, A.V. Oliveira, S.G. de. Jaboticabal, FUNEP. 616p.

PIMENTEL, R. V. (2006). Uma análise da competitividade da bananicultura em Santa Catarina. Monografia (Graduação) - Universidade Federal de Santa Catarina curso de Graduação em Ciências Econômicas, Florianópolis, ago. 2006.

SALMAN, A. K.; et al. Metodologias para avaliação de alimentos para ruminantes domésticos. Embrapa Rondônia-Documentos (INFOTECA-E), 2010.

SANTOS, F. G. B. Substratos para produção de mudas utilizando resíduos agroindustriais. Dissertação (Mestrado) - Pós-graduação em Ciência do solo da Universidade Federal Rural de Pernambuco, Recife (PE), 2006.

SENGER, C. C. D. et al. Evaluation of autoclave procedures for fibre analysis in forage and concentrate feedstuffs. Animal Feed Science and Technology, v.146, p. 169-174.

SILVA, R. R. et al. Efeito da ração farelada e peletizada sobre o comportamento ingestivo de bezerros Holandeses. Archivos de Zootecnia, v. 56, n. 214, p. 227-238, 2007.

SILVA, D. J.; QUEIROZ, A. C. Análise de alimentos: métodos químicos e biológicos. $3^{\text {a }}$ ed. Viçosa: UFV.p. 235.2006.

SNIFFEN, C. J. et al. net carbohydrate and protein system for evaluating cattle diets: II. Carbohydrate and protein availability. Journal of Animal Science, v.70, n.11, p. 35623577, 1992.

SOUZA, C. F. et al. Revista Brasileira de Saúde e Produção Animal, v. 17, n. 1, 2016.

TOKARNIA, C. H.; DÖBEREINER, J.; PEIXOTO, P. V. Deficiências minerais em animais de fazenda, principalmente bovinos em regime de campo. Pesquisa

Veterinária Brasileira, v. 20, n. 3, p. 127-138, 2000. 
VALADARES FILHO, S. C. et al. BR-CORTE 3.0. Cálculo de exigências nutricionais, formulação de dietas e predição de desempenho de zebuínos puros e cruzados. 2016.

VARGAS, E., LOBO, M. V. Fósforo fítico em matérias primas de origem vegetal usadas em la alimentación animal de Costa Rica. Agronomía Costariquense. v.16, n.1, p.139-143

Recebido em: 05/11/2021

Aprovado em: 05/12/2021

Publicado em: 10/12/2021 